\title{
A TECHNIQUE FOR SHIPPING HIPPOBOSCID PUPARIA (DIPTERA) ${ }^{1}$
}

BY I. BARRY TARSHIS

812 Montclaire Ave., Frederick, Maryland

Special techniques have been developed for shipping dipterous insects. Geigy (1948) devised and used a cold temperature cabinet which was kept at $8.0^{\circ} \mathrm{C}$. $\left(46.8^{\circ} \mathrm{F}\right.$.) for shipping adult tsetse flies of the species Glossina palpalis from Tropical Africa (Congo) to Basle, Switzerland, via air express. Brennan and Mail (1954) successfully shipped adult mosquitoes of the species Culex tarsalis in a cold temperature cabinet that employed Sno-Gel Refreezants (Model R10-8) for temperature control. Adult hippoboscid flies of the species Pseudolynchia canariensis were successfully shipped via air express in cardboard mailing tubes for a distance of several hundred miles by the writer (Tarshis, 1953). (This method was only successful when transit took but a day to a day and a half and the temperature was moderate.) The author (Tarshis, 1954) also transported live hippoboscid flies (Stilbometopa impressa and Lynchia hirsuta) in a cold temperature cabinet, maintained at around $7.0^{\circ} \mathrm{C}$. $\left(44.6^{\circ} \mathrm{F}\right.$.), distances of 70 to 300 miles in an automobile.

During studies now being conducted by the author on the biology of Egyptian hippoboscids, an attempt was made to again ship live adult flies in mailing tubes, but the flies always arrived dead. The great distance and consequent time involved in shipping flies from Egypt to Maryland readily explains this lack of success. No attempt was made to ship the flies in refrigerated con-

\footnotetext{
${ }^{1}$ The author wishes to express sincere appreciation to Lt. Com. Harry Hoogstraal, Head, Zoology Dept., NAMRU - 3, Cairo, Egypt for obtaining and sending the puparia and for his continuing help and interest in this work.
} 
tainers, as was accomplished in the above described works, since the cost of such containers and their shipment would be prohibitive; it is also doubtful if any commonly available refrigerants would maintain the necessary low temperature over such a prolonged period (10 to 15 days).

The problem of how to ship live adult hippoboscid flies such a long distance was obviated when experiments showed that puparia of the flies could be shipped this distance economically, simply and most successfully via air express.

The puparia were packed in the following manner for shipment. Several puparia were loosely wrapped in a piese of cleansing tissue and then the tissue-wrapped puparia were put into a shell vial which had a small piece of cotton in the bottom. The number of puparia in a vial would vary with the size of the puparia and the vial. For these shipments a maximum of five puparia of Hippobosca longipennis and three puparia of $H$. equina were placed in each $15 \times 40 \mathrm{~mm}$. vial. The puparia could also be put one or two at a time unwrapped into the vials with cotton under and over each succeeding one or two puparia. The vial was plugged with cotton or capped with a plastic screw-on cap. Five or six vials were then placed into a cardboard mailing tube padded all around the inside and bottom with cotton to prevent the vials from breaking and the puparia from being severely jarred.

Upon arrival in Frederick, Maryland, the puparia were removed from the vials and placed into individual rearing vials $(25 \times 55 \mathrm{~mm}$. $)$ covered with 10 -mesh nylon bcbbinette. The vials containing the puparia were then placed into an incubator set at $26.5^{\circ} \mathrm{C}$. $\left(79.7^{\circ} \mathrm{F}\right.$.). Adult flies of $H$. longipennis emerged from puparia in from 26 to 31 days (from the date of collection in Egypt to date of emergence in Maryland). Adult flies of $H$. equina emerged in 29 days under the same conditions. This shipping method could be employed for puparia of all viviparous flies. 


\section{Literature Cited}

GeIGy, R.

1948. Elevage de Glossina palpalis. Acta Tropica, 5:201-218.

Brennan, J. M., and MaIL, G. A.

1954. A technic for shipping live mosquitoes with particular reference to Culex tarsalis. Science, 119 (3092):443-444.

Tarshis, I. B.

1953. The transmission of Haemoproteus lophortyx O'Roke of the valley California quail by hippoboscid flies of the species stilbometopa impressa (Bigot) and Lynchia hirsuta Ferris and the elucidation of the biology of these ectoparasites. Manuscript of Ph.D. Thesis, Deposited in Library, University of California, Berkeley, California.

Tarshis, I. B.

1954. Transporting live hippoboscids (Diptera). Psyche, 61(2):58-62. 

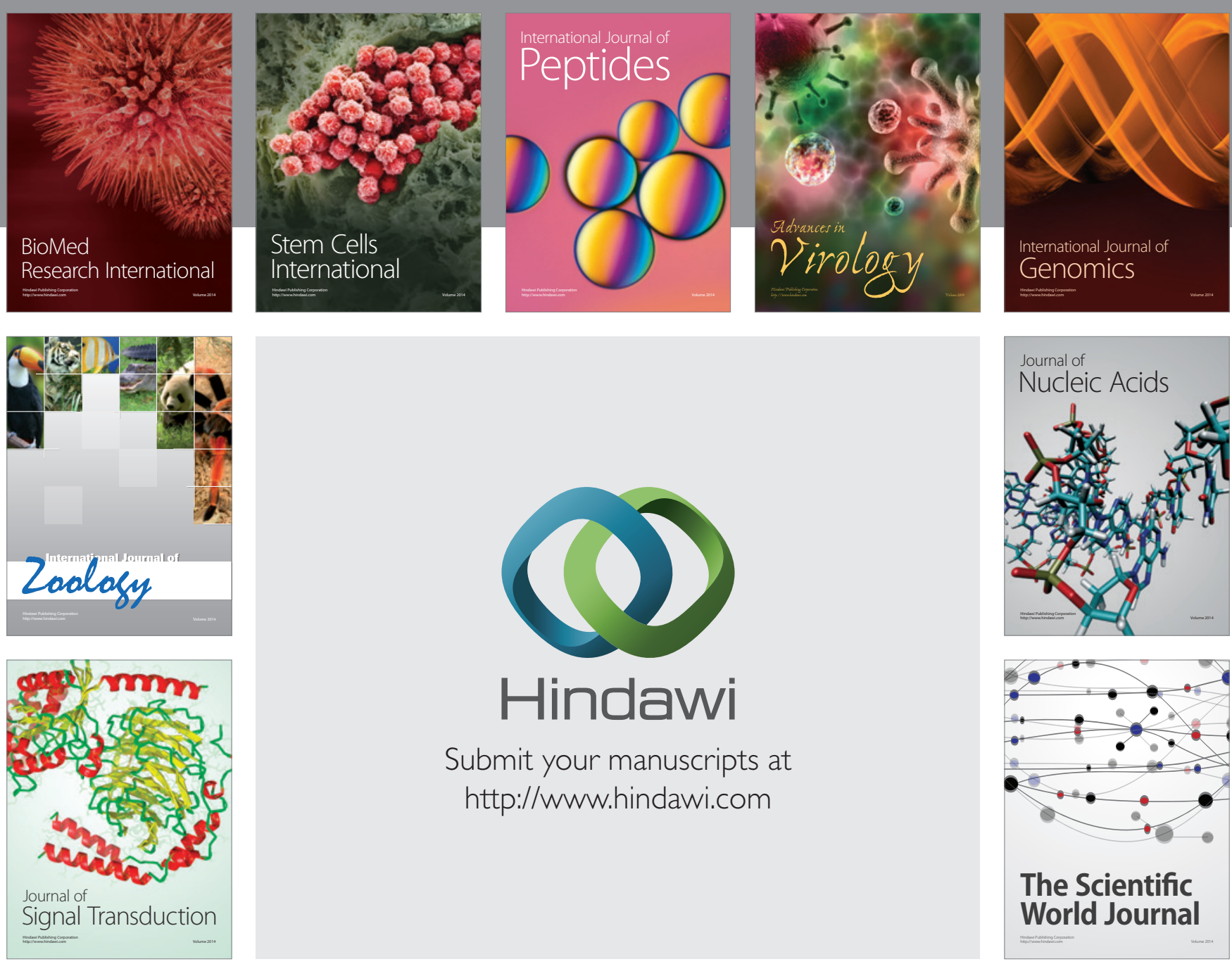

Submit your manuscripts at

http://www.hindawi.com
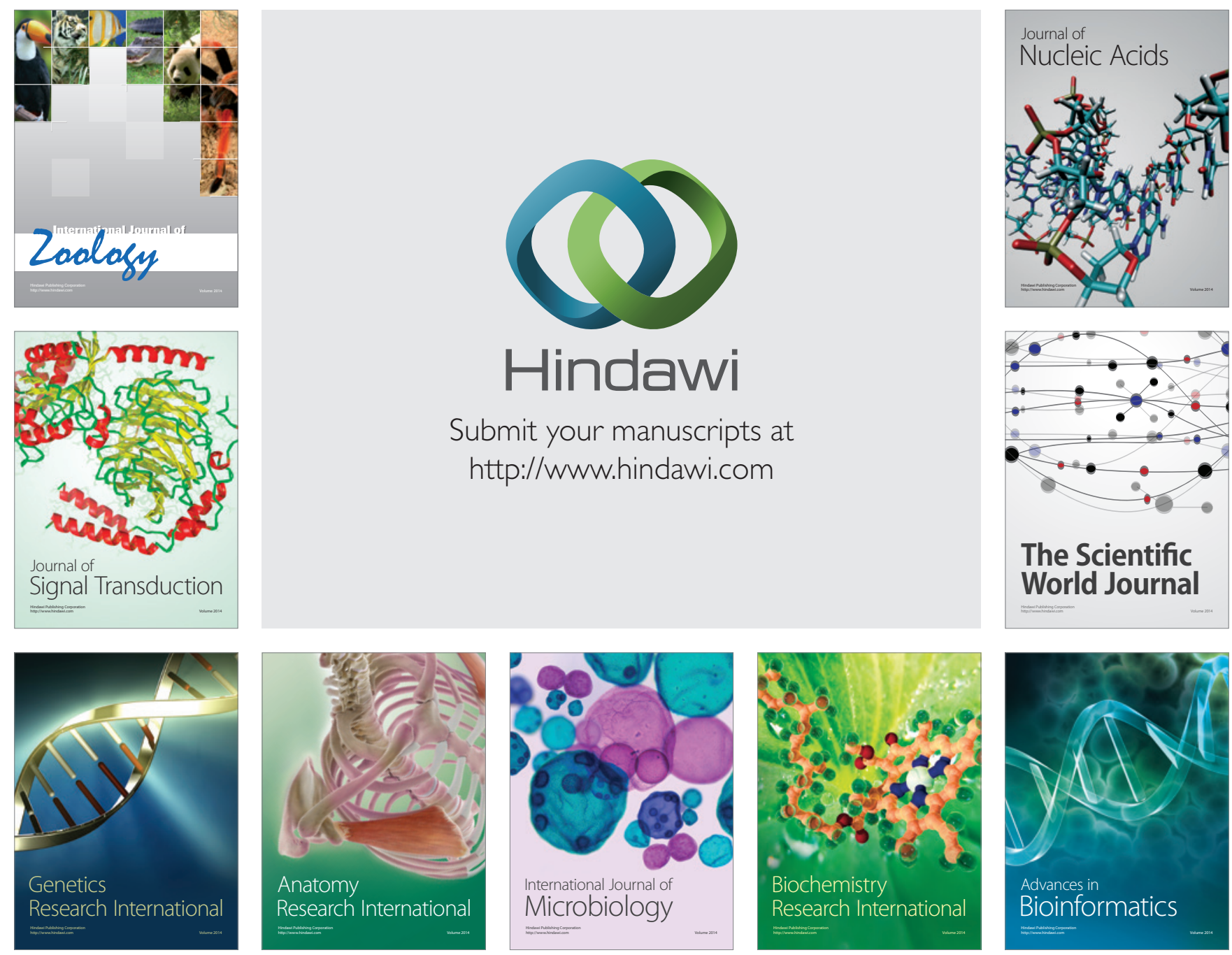

The Scientific World Journal
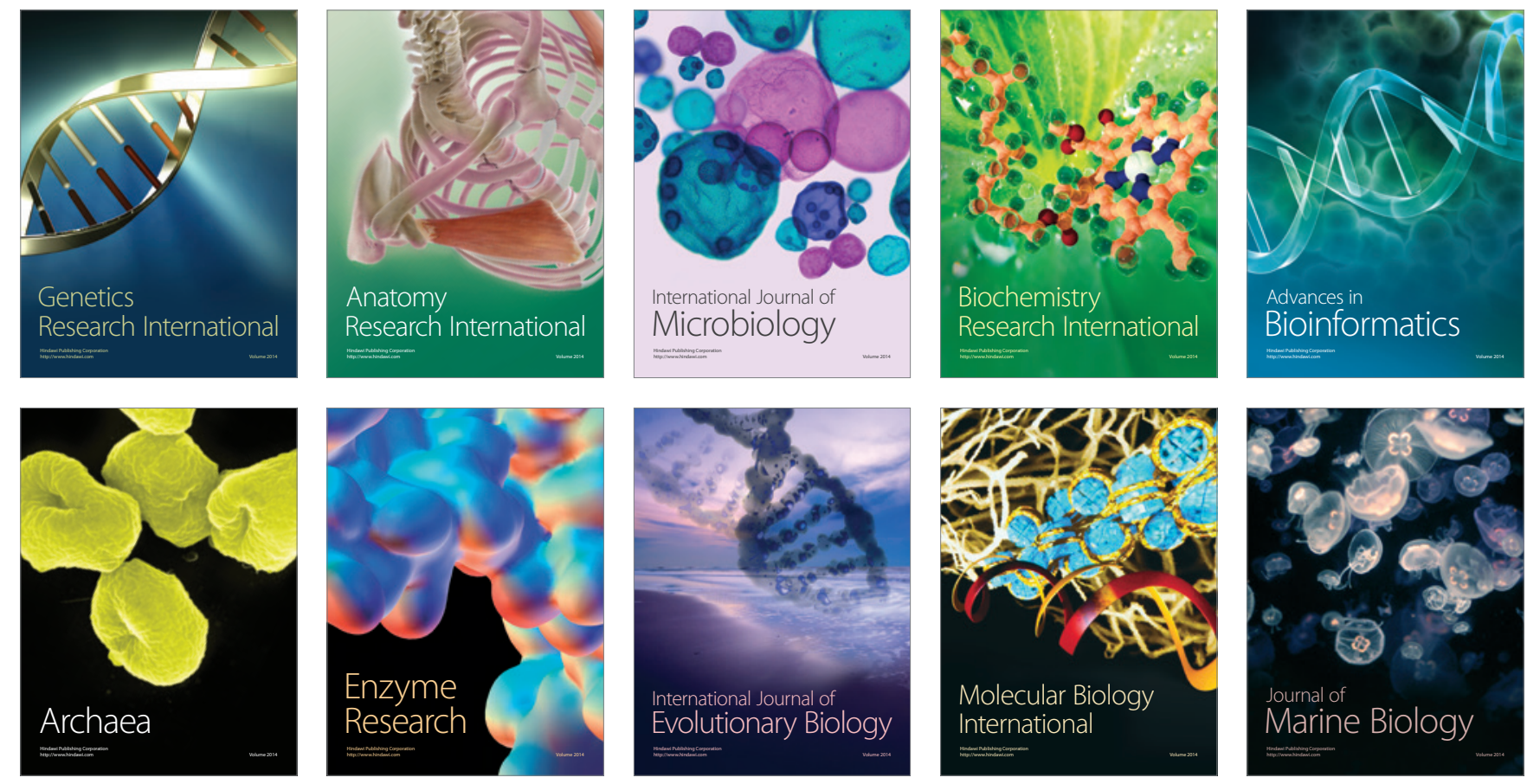